
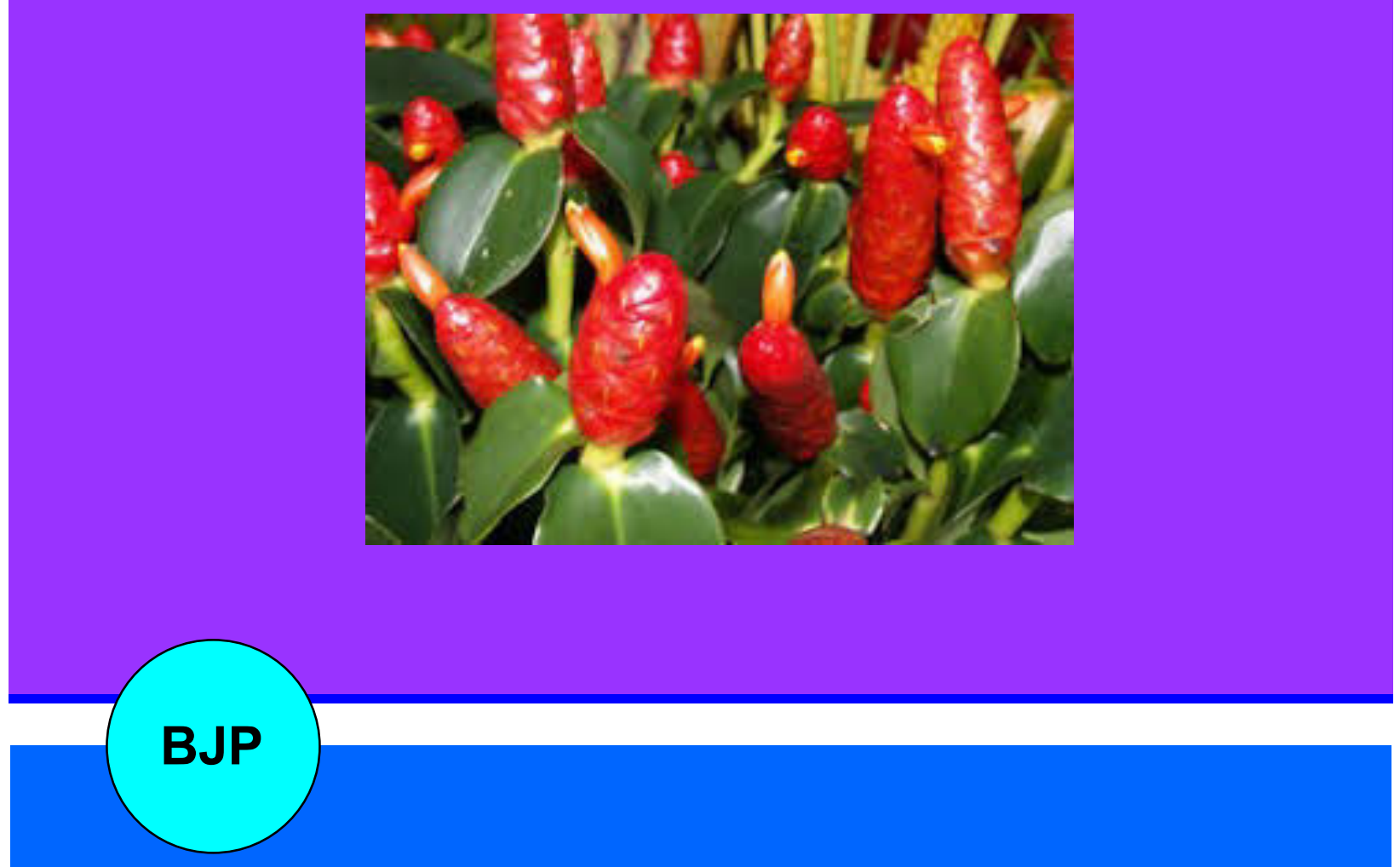

Bangladesh Journal of Pharmacology

Research Article

Chemical investigation of the leaf and rhizome essential oils of Zingiber zerumbet (L.) Smith from Bangladesh 
Abstracted/indexed in Academic Search Complete, Asia Journals Online, Bangladesh Journals Online, Biological Abstracts, BIOSIS Previews, CAB Abstracts, Current Abstracts, Directory of Open Access Journals, EMBASE/Excerpta Medica, Global Health, Google Scholar, HINARI (WHO), International

Pharmaceutical Abstracts, Open J-gate, Science Citation Index Expanded, SCOPUS and Social Sciences Citation Index;

ISSN: $1991-0088$

\title{
Chemical investigation of the leaf and rhizome essential oils of Zin- giber zerumbet (L.) Smith from Bangladesh
}

\author{
Md. Nazrul Islam Bhuiyan, Jasim Uddin Chowdhury and Jaripa Begum \\ Medicinal and Aromatic Plants Research Division, BCSIR Laboratories, P.O. Chittagong Cantonment, \\ Chittagong 4220, Bangladesh.
}

\begin{tabular}{|c|c|}
\hline \multicolumn{2}{|l|}{ Article Info } \\
\hline Received: & 22 May 2008 \\
\hline Accepted: & 18 July 2008 \\
\hline Available Online: & 9 August 2008 \\
\hline \multicolumn{2}{|c|}{ DOI: $10.3329 /$ bjp.v4i1.845 } \\
\hline \multicolumn{2}{|c|}{$\begin{array}{l}\text { Cite this article: } \\
\text { Bhuiyan MNI, Chowdhury JU, } \\
\text { Begum J. Chemical investigation of } \\
\text { the leaf and rhizome essential oils } \\
\text { of Zingiber zerumbet (L.) Smith from } \\
\text { Bangladesh. Bangladesh J Pharma- } \\
\text { col. 2009; 4: 9-12. }\end{array}$} \\
\hline
\end{tabular}

\section{Abstract}

Zingiber zerumbet (L.) Smith leaf and rhizome oils, obtained by hydrodistillation, were analyzed by gas chromatography mass spectroscopy (GC-MS). Twentynine components were identified in the leaf oil. The major components were zerumbone $(37.0 \%)$; a-caryophyllene $(16.4 \%)$ and camphene $(9.2 \%)$. Thirty components were identified in rhizome oil with the main components being in zerumbone (46.8\%); a-caryophyllene (19.0\%) and 1,5,5,8-tetramethyl-12oxabicyclo[9.1.0]dodeca-3,7-diene (4.3\%). The compositions of both oils varied qualitatively and quantitatively.

\section{Introduction}

Zingiber zerumbet (L) Smith, a member of the family Zingiberaceae is well known as Jangli adha in Bangladesh. The plant is widely cultivated in village gardens in the tropics for its medicinal properties and as a marketable spice (Saadiah and Halijah, 1995). It grows in the edges of the forests, village thickets in partial shade. It is distributed in Bangladesh, India, Malaysia, Nepal and Srilanka (Anonymous, 1976). It has been reported that plants from this family have antiinflammatory (Jaganath and $\mathrm{Ng}$, 2000; Somchit and Shukriyah, 2003), anti-ulceration (Mascolo et al., 1989), anti-oxidant (Agrawal et al., 2000) and antimicrobial properties (Nakatani, 2000). It is used to treat stomach aches in Indonesian traditional medicine under the name Jamu (Burkill, 1966). In Polynesia it is an ingredient of several medical preparations used to treat ear inflammation and diarrhea (Petard, 1986). It is used in local traditional medicine as a cure for swelling, sores and loss of appetite. The juice of the boiled rhizomes has also been used as a medicine for worm infestation in children. The volatile oil of the rhizomes has been shown to contain zerumbone, humulene and camprene
(Hasnah, 1991; Srivastava et al., 2000). On Reunion Island Z. zerumbet is grown only in gardens and is used to treat severe sprains in horses and to relieve rheumatic pain. The rhizome oil of Z. zeruibet has been the subject of many studies, especially in India.

Dev (1960) isolated and determined the structure of zerumbone. Nigam and Levi (1963) identified, among other constituents, $\alpha$-humulene, zerumbone, and humulene monoxide. Damodaran and Dev (1968) characterized humulene oxides I, II and III, humulenols I and II, caryophyllene oxide, $\beta$-caryophyllene, dihydrophotozerumbone and photo-zerumbone. Chhabra et al. (1975) found zerumbone epoxide. In oil from Fiji, Duve (1980) found highest levels of zerumbone (59\%). Dung et al. (1995) found high proportions of (Z)nerolidol (22-36\%), which was absent from rhizomes, in extracts of stems, leaves and flowers, and found zerumbone to predominate in leaves. Srivastava et al. (2000) found in similar proportions curzerenone $(14.4 \%)$, zerumbone $(12.6 \%)$ and camphor (12.8\%). Chane-Ming et al. (2003) reported that rhizomes were rich in zerumbone (37\%), a-humulene (14.4\%) and camphene $(13.8 \%)$ and leaves were rich in trans- 
nerolidol (21.4\%), $\beta$-caryophyllene $(6.9 \%)$ and linalool $(7.7 \%)$. The characteristics of the oils from the leaves and rhizomes of $Z$. zerumbet allow them to be identified unequivocally. Lechat-Vahirua et al. (1993) reported also the presence of zerumbone $(65.3 \%)$ as major compounds in the oil from French polynesia. There are no previous references in literature about these Bangladeshi oils. In this work we have determined the chemical composition of leaf and rhizome oils of $Z$. zerumbet. These features allow it to be identified for medicinal use and classified among the other ginger oils available in the international market.

\section{Materials and Methods}

\section{Plant material}

The plant materials of Z. zerumbet were collected from the plants grown in the campus of BCSIR Laboratory, Chittagong during October 2007. A voucher specimen (Y-569) was deposited in the herbarium of BCSIR Laboratory, Chittagong.

\section{Extraction of essential oil}

Samples of leaf were harvested from healthy, wellgrown, two-year-old plants. Freshly harvested leaves (500 g) and rhizome (200 g) were grounded in a blender separately. The grounded leaves and rhizome were subjected to hydrodistillation using a modified Clevenger-type glass apparatus for 4 hours for isolation of oils separately. The oil samples were stored at $0^{\circ} \mathrm{C}$ in airtight containers after drying them over anhydrous sodium sulfate and filtered before going to GC-MS analysis.

\section{GC-MS analysis}

The essential oil from leaves and rhizomes of $Z$. zerumbet were analyzed by GC-MS electron impact ionization (EI) method on GC-17A gas chromatograph (Shimadzu) coupled to a GC-MS QP 5050A mass spectrometer (Shimadzu); fused silica capillary column (30 m $\times 2.5 \mathrm{~mm} ; 0.25 \mathrm{~mm}$ film thickness), coated with DB-5 (J \& W); column temperature $100^{\circ} \mathrm{C}(2 \mathrm{~min})$ to $250^{\circ} \mathrm{C}$ at the rate of $3^{\circ} \mathrm{C} / \mathrm{min}$; carrier gas, helium at constant pressure of $90 \mathrm{Kpa}$. Acquisition parameters full scan; scan range 40-350 amu.

\section{Identification of the compounds}

Compound identification was done by comparing the NIST library data of the peaks with those reported in literature, mass spectra of the peaks with literature data. Percentage composition was computed from GC peak areas on DB-5 column without applying correction factors.

\section{Results and Discussion}

The volatile compounds were identified in the leaves and rhizomes oil of $Z$. zerumbet from Bangladesh were 29 and 30 respectively (Table I). The oil yields were $0.01 \%$ and $1.1 \%$ respectively. The leaves oil were rich in zerumbone $(37.0 \%)$; $\alpha$-caryophyllene $(16.4 \%)$; camphene $(9.2 \%) ; \quad$ 1,2-dihydropyridine,1-(1-oxobutyl),(5.8\%); 3-cyclo hexen-1-carboxaldehyde, 3,4-dimethyl(3.9\%); caryophyllene $(3.3 \%)$; camphor $(2.7 \%)$; caryophyllene oxide (2.5\%); $\alpha$-pinene $(2.2 \%)$; eucalyptol $(1.7 \%)$ and longipinene, [E]-(1.7\%). The rhizome oil was rich in zerumbone $(46.8 \%) ; \alpha$-caryophyllene $(19.0 \%)$; 1,5,5,8-tetramethyl-12-oxabicyclo[9.1.0]dodeca-3,7diene $(4.3 \%)$; caryophy-llene $(4.0 \%)$; caryophyllene oxide $(3.7 \%)$; camphene $(3.6 \%)$; camphor $(2.8 \%)$; kauran -18-al, 17-(acetyloxy)-, (4.beta.) (2.2\%); 1H-cycloprop[e] azulen-4-ol, deca-hydro-1,1,4,7-tetramethyl-, [1ar(1a.alpha., 4.beta., 4a.beta., 7.alpha.,7a.beta.,7b.alpha.)](1.9\%); eucalyptol (1.3\%) and $\alpha$-pinene (1.2\%). Results showed that the oils were complex mixture of numerous compounds, many of which were present in trace amounts. It is worth mentioning here that there is great variation in the chemical composition of leaves and rhizomes oils.

Zerumbone and $\alpha$-caryophyllene are the main common component in leaves and rhizomes oils. Zerumbone is a anti-cancer bioactive compound (Sharifah et al., 2007). Zerumbone, $\alpha$-caryophyllene, caryophyllene, camphor, caryophyllene oxide, limonene, $\alpha$-pinene, eucalyptol, camphene, 3-carene, linalool, borneol, 4-terpineol and cycloheptane, 4-methylene-1-methyl-2-(2-methyl-1propen-1-1-yl)-1-vinyl were observed as the fourteen versatile common compounds present in both the oils with variations in percent content (Table I). On the other hand, comparison of our oils composition with those reported from different places in the world earlier showed that our oil is especially different to others. But it is very interesting to note that comparison of our results reported on the leaf oil composition from the different places showed different results in the percentage content of some of the major and minor constituents. Zerumbone and $\alpha$-caryophyllene, which have been reported as major constituents in our oils as well as in almost all the leaves and rhizomes oils of the world (Vahirua et al., 1993; Dung et al., 1993; Chane et al., 2003; Srivastava et al., 2000; Chhabra et al., 1975; Duve, 1980; Nigam and Levi, 1963) were either absent or present in trace amounts in the oil reported. This confirms that the variations in the cultivar reported are not due to geographic divergence and ecological conditions but that is due to different chemotype than ours.

On the basis of above fact it may be concluded that $Z$. zerumbet, growing widely in Bangladesh, may be uti- 


\begin{tabular}{|c|c|c|c|c|}
\hline \multicolumn{5}{|c|}{ Table I } \\
\hline \multicolumn{5}{|c|}{ Constituents of leaf and rhizome essential oil from Zingiber zerumbet } \\
\hline Peak No. & Name of constituents of leaf essential oil & $\%$ & Name of constituents of rhizome essential oil & $\%$ \\
\hline 1 & Tricyclene & 0.6 & a-Pinene & 1.2 \\
\hline 2 & a-Pinene & 2.2 & Camphene & 3.6 \\
\hline 3 & Camphene & 9.2 & 3-Carene & 0.8 \\
\hline 4 & 3-Carene & 1.0 & $\beta$-Cymene & 0.2 \\
\hline 5 & Eucalyptol & 1.7 & Limonene & 0.9 \\
\hline 6 & Limonene & 1.1 & Eucalyptol & 1.3 \\
\hline 7 & Linalool & 0.9 & Linalool & 0.6 \\
\hline 8 & Camphor & 2.7 & Camphor & 2.8 \\
\hline 9 & Borneol & 0.5 & Borneol & 0.3 \\
\hline 10 & Bornel & 0.8 & 4-Terpineol & 0.2 \\
\hline 11 & 4-Terpineol & 0.5 & $\beta$-Terpinyl acetate & 0.3 \\
\hline 12 & a-Terpineol & 0.5 & Caryophyllene & 4.0 \\
\hline 13 & Caryophyllene & 3.3 & a-Caryophyllene & 19.0 \\
\hline 14 & a-Caryophyllene & 16.4 & 2,4-Diisopropenyl-1-methylcyclohexane & 0.5 \\
\hline 15 & $\begin{array}{l}\text { Cycloheptane, 4-methylene-1-methyl-2-(2- } \\
\text { methyl-1-propen-1-1-yl)-1-vinyl }\end{array}$ & 0.7 & Anisole, p-styryl- & 0.4 \\
\hline 16 & $\begin{array}{l}\text { 1,6,10-Dodecatrien-3-ol, 3,7,11-trimethyl, -[S } \\
\text {-(z)] }\end{array}$ & 0.5 & trans-Nerolidol & 0.5 \\
\hline 17 & Caryophyllene oxide & 2.5 & Germacrene D-4-ol & 0.2 \\
\hline 18 & 1,2-Dihydropyridine,1-(1-oxobutyl),- & 5.8 & Caryophyllene oxide & 3.7 \\
\hline 19 & $\begin{array}{l}\text { 3-Cyclohexen-1-carboxaldehyde, 3,4- } \\
\text { dimethyl- }\end{array}$ & 3.9 & $\begin{array}{l}\text { 1,5,5,8-Tetramethyl-12-oxabicyclo[9.1.0] } \\
\text { dodeca-3,7-diene }\end{array}$ & 4.3 \\
\hline 20 & $\begin{array}{l}\text { Azulene 1,2,3,4,5,6,7,8-octahydro-1,4- } \\
\text { dimethyl-7-(1-methylethylidene), -(IS-cis)- }\end{array}$ & 0.5 & $\begin{array}{l}\text { 2-Naphthalenemethanol, 1,2,3,4,4a,5,6,7- } \\
\text { octahydro-.alpha.,.alpha.,4a,8-tetramethyl-, } \\
\text { (2R-cis)- }\end{array}$ & 0.4 \\
\hline 21 & 2,6-Dimethyl bicyclo $[3,2,1]$ octane & 0.7 & $\begin{array}{l}\text { Bicyclo[3.1.0]hexane-6-methanol, 2-hydroxy- } \\
\text { 1,4,4-trimethyl- }\end{array}$ & 0.9 \\
\hline 22 & 7-Octylidenebicyclo [4.1.0] heptan- & 0.7 & Kauran-18-al, 17-(acetyloxy)-, (4.beta.)- & 2.2 \\
\hline 23 & $\begin{array}{l}\text { 1,5-Cycloundecadien, 8,8-dimethyl-9- } \\
\text { methylene }\end{array}$ & 1.1 & $\begin{array}{l}\text { 1H-Cycloprop[e]azulen-4-ol, decahydro- } \\
\text { 1,1,4,7-tetramethyl-, [1ar- } \\
\text { (1a.alpha.,4.beta.,4a.beta., } \\
\text { 7.alpha.,7a.beta.,7b.alpha.)]- }\end{array}$ & 1.9 \\
\hline 24 & $\begin{array}{l}\text { 3-Isopropyltricyclo [4.3.1.1] }(2,5) \text { undec -3- } \\
\text { en-10-ol }\end{array}$ & 0.8 & $\begin{array}{l}\text { 4-Isopropenyl-4,7-dimethyl-1-oxaspiro[2.5] } \\
\text { octane }\end{array}$ & 0.2 \\
\hline 25 & $\beta$-Eudesmol & 0.7 & 2-Methylenecholestan-3-ol & 1.0 \\
\hline 26 & Agerospirol & 1.0 & Carveol & 0.9 \\
\hline 27 & $\begin{array}{l}\text { 3a,9-Dimethyldodecahydrocyclohepta [d] } \\
\text { inden-3-one }\end{array}$ & 0.7 & Norethynodrel & 0.2 \\
\hline 28 & trans-Longipinene & 1.7 & Zerumbone & 46.8 \\
\hline 29 & Zerumbone & 37.0 & $\begin{array}{l}\text { Bicyclo[5.3.0]decane, 2-methylene-5-(1- } \\
\text { methylvinyl)-8-methyl- }\end{array}$ & 0.4 \\
\hline 30 & & & $\begin{array}{l}\text { Cycloheptane, 4-methylene-1-methyl-2-(2- } \\
\text { methyl-1-propen-1-yl)-1-vinyl- }\end{array}$ & 0.5 \\
\hline
\end{tabular}

lized as a source for the isolation of natural zerumbone and $\alpha$-caryophyllene respectively. As a result of this study, the essential oil of $Z$. zerumbet has been extracted and its components identified. The high concentration of zerumbone and $\alpha$-caryophyllene in leaf and rhizome oil makes it respectively potentially useful in the medicines because they exhibit anti-inflammatory
(Jaganath and Ng, 2000; Somchit and Shukriyah, 2003), anti-ulceration (Mascolo et al., 1989), anti-oxidant (Agrawal et al., 2000) and antimicrobial properties (Nakatani, 2000). It is worth noting that the oil of $Z$. zerumbet have been reported to be used in folk medicine in the treatment of inflammation, diarrhea and rheumatic pain. 


\section{References}

Agrawal AK, Rao CV, Sairam K, Joshi VK. Antipyretic and analgesic activities of Zingiber zerumbet extracts. Indian J Exp Biol. 2000; 38: 994-98.

Anonymous. The wealth of India. Raw materials. vol. 11. India, CSIR, 1976, pp 89-90.

Burkill HI. Dictionary of the economic products of the Malay Peninsula. Ministry of Agriculture and Coop., Kuala Lumpur, 1966, p 2345.

Chane-Ming J, Vera R, Chalchat JC. Chemical composition of the essential oil from rhizomes, leaves and flowers of Zingiber zerumbet Smith from Reunion Island. J Essent Oil Res. 2003; 15: 202-05.

Chhabra NP, Dhillon RS, Wadia MS, Kalsi PS. Structure of zerumbone oxide: A new sesquiterpene epoxy ketone from Zingiber zerumbet Smith (wild ginger oil). Indian J Chem. 1975; 13: 222-24.

Damodaran NP, Dev S. Studies in sesquiterpenes - XXXIX. Structure of humulenols. Tetrahedron 1968; 24: 4133-42.

Damodaran NP, Dev S. Studies in sesquiterpenes - XXXVII. Sesquiterpenoids from the essential oil of Zingiber zerumbet Smith. Tetrahedron 1968; 24: 4113-22.

Damodaran NP, Dev S. Studies in sesquiterpenes - XXXVIII. Structure of humulene epoxide-I and humulene epoxide-11. Tetrahedron 1968, 24: 4123-32.

Dev S. Sesquiterpenes. XVI. Zerumbone, a monocyclic sesquiterpene ketone. Tetrahedron 1960; 8: 171-80.

Dung NX, Chinh TD, Leclercq PA. Chemical investigation of the aerial parts of Zingiber zerumbet (L.) Sm. from Vietnam. J Essent Oil Res. 1995; 7: 153-57.

Dung NX, Chinh TD, Rang DD, Leclercq PA. The constituents of the rhizome oil of Zingiber zerumbet (L.) Sm. from Vietnam. J Essentl Oil Res. 1993; 5: 553-55.

Duve RN. Highlights of the chemistry and pharmacology of wild ginger (Zingiber zerumbet Smith). Fiji Agric J. 1980; 42:
$41-43$.

Hasnah MS. Chemical constituents of some medicinal plants of zingiberaceae: Medicinal products from tropical rain forest. Proceedings of the Concerence, Forest Research Institute Malaysia, Kuala Lumpur, 1991; 2: 299-304.

Jaganath IB, Ng LT. Herbs: The green pharmacy of Malaysia. Vinpress Sdn. Bhd. and Malaysia Agricultural Research and Development Institute, 2000, pp 95-99.

Mascolo N, Jain R, Jain SC, Capasso FJ. Ethnopharmacologic investigation of. ginger (Zingiber officinale). Ethnopharmacology 1989; 27: 129-40.

Nakatani N. Phenolic anti-oxidants from herbs and species. Biofactors 2000; 13: 141-46.

Nigam LC, Levi L. Column and gas chromatographic analysis of oil of wild ginger: Identification and estimation of some new constituents. Can J Chem. 1963; 41: 1726-30.

Petard P. Quelques plantes utiles de la Polynesie et Ra'au Tahiti. Papeete, Haere Po no Tahiti, 1986, p 1876.

Saadiah MS, Halijah I. Proceedings of the National Convention on Herbal medicine. Vol. 21, Kuala Lumpur, Forest Research Institute Malaysia, 1995, pp 205-07.

Sharifah Sakinah SA, Tri Handayani S, Azimahtol Hawariah LP. Zerumbone induced apoptosis in liver cancer cells via modulation of Bax/Bcl-2 ratio. Cancer Cell Int. 2007; 7: 4.

Somchit Nhareet M, Shukriyah Nur MH. Anti-inflammatory property of ethanol and water extracts of Zingiber zerumbet. Indian J Pharmacol. 2003; 35: 181-82.

Srivastava AK, Srivastava SK, Shah NC. Essential oil composition of Zingiber zerumbet (L.) Sm. from India. J Essent Oil Res. 2000; 12: 595-97.

Lechat-Vahirua I, Francois P, Menut C, Lamely G, Bessiere JM. Aromatic plants of French polynesia. 1. Constituents of the essential oils of rhizomes of three Zingiberaceae: Zingiber zerumbet Smith, Hedychium coronarium Koenig and Etlingera cevuga Smith. J Essent Oil Res. 1993; 5: 55-59.

\footnotetext{
Author Info

Md. Nazrul Islam Bhuiyan (Principal contact)

I e-mail: nazrul119@yahoo.com
} 